Jurnal Progres Ekonomi Pembangunan (JPEP)

Volume 5, Nomor 1, Tahun 2020

Page: 83-94

http://ojs.uho.ac.id/index.php/JPEP

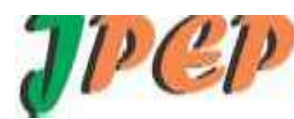

e-ISSN: 2052-5171

\title{
DAMPAK TRANSFORMASI STRUKTUR EKONOMI INDONESIA TERHADAP MOBILITAS PEKERJA ANTAR SEKTOR
}

\author{
Tajuddin \\ Fakultas Ekonomi dan Bisnis Universitas Halu Oleo Kendari \\ Email: tajuddin@uho.ac.id \\ Muhammad Syarif \\ Fakultas Ekonomi dan Bisnis Universitas Halu Oleo Kendari \\ Email: muh.syarif@uho.ac.id \\ M. Natsir \\ Fakultas Ekonomi dan Bisnis Universitas Halu Oleo Kendari \\ Email: dr_m.natsir@uho.ac.id \\ Syamsir Nur \\ Fakultas Ekonomi dan Bisnis Universitas Halu Oleo Kendari \\ Email: syamsir_nur@uho.ac.id
}

\begin{abstract}
ABSTRAK
Pembangunan adalah proses perubahan kondisi yang "kurang baik" menjadi kondisi yang "lebih baik". Perubahan yang terjadi dalam proses pembangunan mengandung makna bahwa pembangunan bersifat dinamis, bergerak, berubah dan akan mengalami transformasi. Secara historis pembangunan ekonomi dikaitkan dengan perubahan struktural dalam perekonomian nasional. Negara sedang berkembang biasanya ditandai oleh kontribusi sektor pertanian yang paling besar, namun dalam perkembangan selanjutnya kontribusi sektor industri meningkat sebaliknya kontribusi sektor pertanian menurun, dan kemudian setelah perekonomian mencapai tingkat yang cukup tinggi peranan sektor jasa meningkat dan menjadi komponen utama dari perekonomian. Pada mulanya Indonesia terkenal dengan negara agraris, dikarenakan sektor agraris merupakan penghasil berbagai pangan dan bahan pagan yang melimpah serta menyerap banyak tenaga kerja. Namun saat ini Indonesia merupakan salah satu negara yang banyak mengimpor bahan pangan dari negara lain misalnya kedelai, gula, garam dan beras. Penelitian ini bertujun untuk menganalisis dan mengetahui dampak transformasi struktur ekonomi terhadap mobilitas pekerja antar sektor dalam perekonomian Indonesia. Secara keseluruhan penelitian ini menggunakan data sekunder berupa Produk Domestic Bruto (PDB) dan penyerapan teaga kerja pada semua sektor perekonomian yang diperoleh dari Badan Pusat Statistik (BPS). Data diolah dan dianalisis dengan metode statistik derkriptif yang kemudian hasilnya dipaparkan dalam matriks dan gambar. Hasil penelitian menujukkan bahwa di Indonesia baik berdasarkan PDB maupun penyerapan tenaga kerja telah terjadi transformasi struktur ekonomi dari sektor primer ke sektor tersier. Transformasi struktur ekonomi tersebut diikuti oleh mobilitas pekerja dari sektor primer ke sektor sekunder.
\end{abstract}

Kata Kunci: Mobilitas Pekerja Antar Sektor Perekonomian

\begin{abstract}
Development is the process of changing "less good" conditions to "better" conditions. Changes that occur in the development process mean that development is dynamic, moving, changing and will undergo transformation. Historically economic development has been associated with structural changes in the national economy. Developing countries are usually characterized by the greatest contribution of the agricultural sector, but in subsequent developments the contribution of the industrial sector increases otherwise the contribution of the agricultural sector decreases, and then after the economy reaches a fairly high level the role of the service sector increases and becomes a major component of the economy. In the beginning, Indonesia was famous with an agrarian country, because the agrarian sector was a producer of various abundant food and pagan materials and absorbed a lot of labor. But now Indonesia is one of the countries that imports food from other countries such as soybeans, sugar, salt and rice. This study aims to analyze and determine the impact of economic structure transformation on the mobility of workers between sectors in the Indonesian economy. Overall this study uses secondary data in the form of Gross Domestic Product (GDP) and employment absorption in all economic sectors obtained from the Central Statistics Agency (BPS). The data is processed and analyzed by using descriptive statistical methods which are then presented in a matrix and image. The results showed that in Indonesia based on
\end{abstract}


Jurnal Progres Ekonomi Pembangunan (JPEP)

Volume 5, Nomor 1, Tahun 2020

Page: 83-94

http://ojs.uho.ac.id/index.php/JPEP

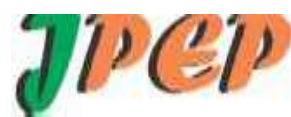

both GDP and employment there has been a transformation of the economic structure from the primary sector to the tertiary sector. The transformation of the economic structure is followed by the mobility of workers from the primary sector to the secondary sector.

Keywords: Mobility of Workers Between Economic Sectors

\section{PENDAhUluAN}

Negara sedang berkembang biasanya ditandai oleh kontribusi sektor pertanian yang paling besar, namun dalam perkembangan selanjutnya kontribusi sektor industri meningkat sebaliknya kontribusi sektor pertanian menurun, dan kemudian setelah perekonomian mencapai tingkat yang cukup tinggi peranan sektor jasa meningkat dan menjadi komponen utama dari perekonomian. Pergeseran kontribusi terbesar dari sektor pertanian ke sektor industri atau jasa terhadap Produk Domestik Bruto (PDB) disebut dengan transformasi struktur ekonomi.

Secara agregat PDB Indonesia dalam sepuluh tahun terakhir mengalami peningkatan. Pada Tahun 2010 PDB Indonesia berjumlah Rp. 6,68 juta miliar menjadi Rp.10,49 juta miliar pada Tahun 2019. Jika dilihat berdasarkan komposisinya, pada Tahun 2010 sektor pertanian merupakan kontributor terbesar kedua $(14,31 \%)$ setelah industri pengolahan (22,63\%). Pada Tahun 2019 konfigurasi tersebut tidak berubah namun kontribusi sektor pertanian semakin menurun $(12,90 \%)$ sama halnya dengan sektor industri pengolahan turun menjadi 21,68 persen, hal ini berarti terjadi pergeseran peran dari sektor primer ke sektor tersier.

Beberapa tahun yang lalu Indonesia terkenal sebagai negara agraris, negara yang mayoritas penduduknya bekerja di sektor pertanian sekaligus sebagai negara penghasil bahan pangan dan perkebunan yang melimpah. Namun saat ini Indonesia merupakan salah satu negara yang banyak mengimpor bahan pangan dari negara lain sebut saja pada Tahun 2018 Indonesia mengimpor kedelai sebanyak 2,5 juta ton (U\$ 1,1 juta); gula 101,1 ribu ton (U\$ 41.273); garam 2,8 juta ton (U\$ 90.651) bahkan Indonesia mengimpor beras sebanyak 2,25 juta ton. Para pakar mengemukakan bahwa faktor supply-demand menjadi penyebab terjadinya impor bahan pangan. Ada gejala high demand but less supply. Peningkatan permintaan bahan pangan seiring dengan peningkatan jumlah penduduk namun tidak sebanding dengan produksi pangan. Salah satu faktor penyebabnya adalah semakin sempitnya lahan pertanian akibat konversi penggunaan lahan pertanian mejadi kawasan pemukiman, industri maupun perkantoran.

Negara agraris, disamping sektor pertanian sebagai sektor utama dalam pembentukan PDB yang tidak kalah pentingnya adalah sektor pertanian juga menyerap banyak tenaga kerja sehingga wajar ketika itu sektor pertanian disebut sebagai "katup pengaman". Meskipun tidak terbesar lagi namun daya tampung tenaga kerja pada sektor primer masih cukup besar. Pada Tahun 2019 sebenyak 30,52 persen tenaga kerja terserap pada sektor primer sedangkan sektor sekunder hanya dapat berkontribusi sebesar 14,65 persen dan sektor tersier sebesar 54,83 persen.

Fenomena mobilitas penduduk dari perdesaan ke perkotaan telah dijelaskan oleh Lewis dalam teorinya model dua sektor (Lewis two sector models). Perekonomian terdiri dari perekonomian moderen (perkotaan) dengan industri sebagai sektor utama. Di perdesaan karena pertumbuhan penduduknya tinggi maka akan terjadi kelebihan suplay tenaga kerja dengan tingkat hidup masyarakat pada kondisi subsisten. Lewis mengatakan bahawa di negara sedang berkembang terjadi transformasi struktur ekonomi dari pola perekonomian pertanian subsisten tradisional ke perekonomian yang lebih moderen berorientasi pada kehidupan perkotaan serta memiliki sektor industri manufaktur yang bervariasi dan sektor jasa yang tangguh (Todaro, 2004:133).

Pada berbagai negara yang melakukan analisis transformasi struktur ekonomi, sektor-sektor ekonomi dapat dikelompokkan ke dalam lapangan usaha utama yaitu primer, sekunder dan tersier (Tajuddin, dkk, 2017). Selama periode 10 tahun terakhir (Tahun 2010-2019), kontribusi sektor primer terhadap pembentukan PDB Indonesia terus mengalami penurunan sedangkan sektor sekunder meningkat namun mengalami perlambatan sebaliknya sektor tersier mengalami peningkatan yang konsisten, hal ini menunjukkan bahwa di Indonesia terjadi transformasi struktur ekonomi dari sektor 
Jurnal Progres Ekonomi Pembangunan (JPEP)

Volume 5, Nomor 1, Tahun 2020

Page: 83-94

http://ojs.uho.ac.id/index.php/JPEP

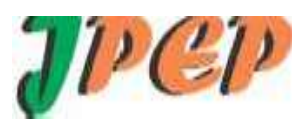

e-ISSN: 2052-5171

primer ke sektor tersier. Artikel ini bertujuan untuk menganalisis dan mengetahui transformasi struktur ekonomi serta dampaknya pada perubahan struktur tenaga kerja dan arus mobilitas pekerja antara sektor dalam perekonomian Indonesia.

\section{KAJIAN LITERATUR}

\section{Teori Transformasi Struktur Ekonomi}

Pegeseran srtuktur ekonomi biasa juga disebut transformasi struktural. Teori ini awalnya dipopulerkan oleh Fisher (1939) dan Clark (1940). Teori transformasi struktur ekonomi fokus pada perubahan produksi dan penggunaan faktor produksi yang digunakan.

Teori perubahan struktur ekonomi juga dikemukakan oleh Chenery. Dari berbagai penelitan yang dilakukan Chenery menyimpulkan bahwa pembangunan merupakan suatu proses pertumbuhan dan perubahan yang dapat diamati dimana ciri-cirinya hampir sama untuk semua negara. Pergeseran struktur ekonomi suatu negara dapat dibedakan berdasarkan persentase tenaga kerja yang berada di sektor primer, sekunder dan tersier (Syrquin, 1988:212). Chenery menjelaskan bahwa proses transformasi struktur akan mencapai taraf yang paling cepat bila pergeseran permintaan domestik ke arah output industri manufaktur diperkuat oleh perubahan yang serupa dalam komposisi perdagangan atau ekspor sebagaimana yang terjadi di negara-negara kelompok Newly Industrialized Countries ( NICs).

Transformasi ekonomi adalah realokasi dinamis yang bersumber dari sektor kurang produktif ke kegiatan atau sektor yang lebih produktif. Transformasi sosial-ekonomi umumnya didefinisikan sebagai suatu proses di mana peningkatan proporsi output ekonomi dan lapangan kerja yang dihasilkan oleh sektor selain pertanian. Proses transformasi ini berkonotasi sebagai pergeseran dari masyarakat berbasis pertanian ke perkotaan, industri dan atau ekonomi berbasis layanan dengan tingkat pertumbuhan GDP tinggi berkelanjutan. Pertumbuhan PDB dikombinasikan dengan penurunan pertumbuhan penduduk tingkat yang dihasilkan dari peningkatan akses pendidikan dan berkualitas kenaikan GDP per kapita yang pada gilirannya mengurangi kemiskinan.

\section{Faktor Yang Mendorong Terjadinya Transformasi Struktur Ekonomi}

Yingmei WU, et, al (2006) menjelaskan bahwa sejak tahun 1950 di Cina telah terjadi transformasi struktur ekonomi melalui perubahan penggunaan lahan. Industrialisasi telah menjadi kekuatan yang paling kuat dari perubahan dalam pembangunan di Changjian. Hampir semua sumber daya daerah diperuntukkan dalam upaya memodernisasi produksi industri dan sistem pembangunan perkotaan (industrialisasi) dan urbanisasi telah menjadi kisah sukses. Berkaitan dengan konversi lahan, (Irawan, 2014) menyatakan bahwa konversi lahan sawah ke penggunaan non pertanian seperti kompleks perumahan, kawasan industri, kawasan perdagangan, dan sarana publik dapat menimbulkan dampak negatif secara ekonomi, sosial, dan lingkungan. Bagi ketahanan pangan nasional, konversi lahan sawah merupakan ancaman yang serius, mengingat konversi lahan tersebut sulit dihindari sementara dampak yang ditimbulkan terhadap masalah pangan bersifat permanen, kumulatif, dan progresif.

Tambunan (2011:6) mengemukakan bahwa perubahan struktur ekonomi terjadi akibat perubahan dari sejumlah faktor antara lain dari sisi permintaan aggregate (AD) dan faktor-faktor dari sisi penawaran anggregate (AS). Dari sisi AD faktor yang sangat dominan adalah perubahan permintaan domestik yang disebabkan oleh kombinasi antara peningkatan pendapatan riil perkapita dan perubahan selera masyarakat. Perubahan permintaan tidak hanya dalam arti konsumsi tetapi juga dalam perubahan komposisi barang-barang yang dikonsumsi. Perubahan komposisi ini dapat dijelaskan dengan Hukum Engel bahwa "makin tinggi pendapatan masyarakat, maka makin sedikit proporsi pendapatan yang digunakan untuk membeli bahan pertanian", sebaliknya proporsi pendapatan yang digunakan untuk membeli barang-barang produksi industri menjadi bertambah besar. Dengan demikian peranan sektor industri akan semakin besar dibandingkan sektor pertanian.

Menurut Komisi Ekonomi PBB untuk Afrika (2013:3), transformasi ekonomi berkaitkan dengan perubahan mendasar dalam struktur ekonomi dan faktor pendorong pertumbuhan ekonomi. 
Jurnal Progres Ekonomi Pembangunan (JPEP)

Volume 5, Nomor 1, Tahun 2020

Page: 83-94

http://ojs.uho.ac.id/index.php/JPEP

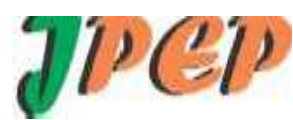

e-ISSN: 2052-5171

Transformasi ekonomi melibatkan: realokasi sumber daya dari kurang produktif ke sektor yang lebih produktif, peningkatan kontribusi manufaktur terhadap PDB, penurunan pangsa lapangan kerja pertanian terhadap total tenaga kerja, pergeseran kegiatan ekonomi dari pedesaan ke perkotaan, dan munculnya ekonomi industri dan jasa modern.

\section{Teori Mobilitas Tenaga Kerja}

Transformasi ekonomi melibatkan pergerakan tenaga kerja dari sektor yang produktivitasnya rendah ke sektor yang kegiatan produktifnya lebih tinggi. Hal ini diterima secara luas bahwa pengurangan kemiskinan dan pertumbuhan ekonomi tidak dapat dipertahankan tanpa transformasi ekonomi dan perubahan produktivitas. Fei-Ranis menjelaskan konsep yang berkaitan dengan transfer tenaga kerja dari sektor pertanian ke sektor industri (Sukirno, 2007:202). Tahapan transfer tenaga kerja dibagi tiga berdasarkan pada produk fisik marginal (MPP) dan upah yang dianggap konstan dan ditetapkan secara eksogenus, sebagai berikut: (1) pada tahap pertama, karena tenaga kerja melimpah maka MPP tenaga kerja sama dengan atau mendekati nol sehingga surplus tenaga kerja yang ditransfer dari sektor pertanian ke sektor industri mempunyai kurva penawaran yang elastis sempurna; (2) Pada tahap kedua, pengurangan satu satuan tenaga kerja di sector pertanian akan menurunkan produksi karena MPP tenaga kerja sudah positif (ruas AB) namun besarnya MPP masih lebih kecil dari tingkat upah W. Transfer tenaga kerja dari pertanian ke industri pada tahap ini mempunyai biaya seimbang yang positif, sehingga kurva penawaran tenaga kerja di sektor industri mempunyai elastisitas positif sejak titik S1. (3) Tahap ketiga adalah tahap komersialisasi di kedua sektor ekonomi, dimana MPP tenaga kerja sudah lebih tinggi dari tingkat upah. Produsen pertanian akan mempertahankan tenaga kerjanya sehingga masing-masing sektor berusaha efisien.

Dalam model Fei Ranis, kecepatan transfer tenaga kerja dari sektor pertanian ke sektor industri tergantung pada: (a) tingkat pertumbuhan penduduk, (b) perkembangan teknologi di sektor pertanian dan (c) tingkat pertumbuhan stok modal di sektor industri dan surplus yang dicapai di sektor pertanian. Dengan demikian keseimbangan pertumbuhan di kedua sektor tersebut menjadi prasyarat untuk menghindari stagnasi dalam pertumbuhan ekonomi nasional. Ini Berarti kedua sektor tersebut harus tumbuh secara seimbang dan transfer serta penyerapan tenaga kerja di sektor industri harus lebih cepat dari pertumbuhan angkatan kerja.

Lewis mengasumsikan bahwa di daerah pedesaan dengan perekonomian tradisional mengalami surplus tenaga kerja. Dalam perekonomian tradisional tingkat hidup masyarakat berada pada kondisi subsisten, hal ini diakibatkan oleh kelebihan penduduk dengan produktivitas marjinal tenaga kerja sama dengan nol. Lewis menjelaskan bahwa kondisi surplus tenaga kerja (surplus labor) sebagai fakta. Jika sebagian tenaga kerja tersebut di tarik dari sektor pertanian, maka sektor itu tidak akan kehilangan outputnya. Pertumbuhan ekonomi umumnya diiringi dengan transformasi struktural dalam perekonomian itu sendiri. Teori ini berhasil dikembangkan oleh Arthur Lewis yang terkenal dengan model surplus tenaga kerja dua sektor dan Hollis Chenery dengan analisa empirisnya tentang pola-pola pembangunan.

Lewis dalam Todaro (2006:68) menjelaskan bahwa perekonomian negara berkembang terdiri atas dua sektor utama, yaitu sektor pertanian yang subsisten dan sektor modern (industri dan jasa). Sektor pertanian adalah sektor pedesaan yang penduduknya melimpah sehingga tenaga kerja juga melimpah (surplus of labour). Kondisi ini secara teknis ditunjukkan oleh marginal produktivitas sama dengan nol. Dengan begitu perpindahan tenaga kerja dari sektor pertanian ke sektor lain sama sekali tidak mempengaruhi produksi di sektor pertanian. Penekanan utama teori ini adalah proses terjadinya perpindahan tenaga kerja dari sektor pertanian pedesaan ke sektor industri perkotaan serta peningkatan outputnya.

Tajuddin (2017) menyimpulkan bahwa berdasarkan output (PDB), pola transformasi struktur ekonomi Indonesia meloncat dari sektor primer langsung ke sektor tersier. Demikian pula Yingmei WU, et, al (2006) mengemukakan bahwa, sejak tahun 1950 di Cina telah terjadi transformasi struktur ekonomi melalui perubahan penggunaan lahan. Industrialisasi telah menjadi kekuatan yang paling kuat dari perubahan dalam pembangunan di Changjian. Hampir semua sumber daya daerah diperuntukkan 
Jurnal Progres Ekonomi Pembangunan (JPEP)

Volume 5, Nomor 1, Tahun 2020

Page: 83-94

http://ojs.uho.ac.id/index.php/JPEP

dalam upaya memodernisasi produksi industri dan sistem pembangunan perkotaan (industrialisasi) dan urbanisasi telah menjadi kisah sukses. Dari analisis regresi yang dilakukan ditemukan bahwa bahwa faktor dominan dalam perubahan penggunaan lahan adalah industrialisasi.

Malunda (2012:5) mengemukakan bahwa telah terjadi transformasi struktur ekonomi di Rwanda (Afrika). Beberapa indikasi terjadinya transformasi ekonomi yaitu: (1) peningkatan yang signifikan dalam investasi sektor swasta sebagai akibat dari pelaksanaan reformasi bisnis dan revisi pajak sejak tahun 2005 meskipun; (2) investasi asing dan dalam negeri memiliki meningkat melebihi investasi lokal dan peningkatan lapangan kerja baru; (3) peningkatan ekspor; (4) peningkatan pendapatan dari pariwisata; (5) pergeseran yang signifikan terhadap produktivitas sektor pertanian yang rendah menjadi pertanian dengan produktivitas yang lebih tinggi karena bererientasi pasar; (6) pengembangan nonpertanian mulai jelas. Margaret MC Milan 2011, menyimpulkan bahwa; terjadi perubahan struktur ekonomi di Nigeria dimana terdapat dua sektor dalam perekonomian yaitu sektor pertanian tradisional di desa (rural) dan sektor industri modern di kota atau urban.

Key-Mu-Yi Jjing Zang, 2011 menyimpulkan bahwa pertumbuhan ekonomi suatu daerah tergantung pada produktivitas yang tinggi dari komponen makro ekonomi yaitu perumbuhan ekspor, efek multiplier, pengeluaran, pertumbuhan, efek multiplier dari perdagangan internasional, pertumbuhan, ekspor berdampak pada pertumbuhan GDP dan pertumbuhan kesempatan kerja. Sudarmono (2006), melakukan penelitian dengan judul Analisis Transformasi Struktural, Pertumbuhan Ekonomi dan Ketimpangan Antar Daerah di Wilayah Pembangunan I Jawa Tengah. Hasil penelitian menunjukkan bahwa Transformasi struktural hanya terjadi di Kabupaten Semarang dan Kabupaten Kendal. Transformasi struktural yang terjadi tidak diikuti oleh pergeseran penyerapan tenaga kerja sektoral dari sektor pertanian ke sektor industri di kedua Kabupaten tersebut. Rumbia, 2016 dalam hasil penelitiannya menyimpulkan bahwa telah terjadi perubahan struktur ekonomi untuk 12 kabupaten/kota di Provinsi Sulawesi Tenggara. Proses perubahan kontribusi masing-masing sektor terhadap pembentukan PDRB bervariasi. Pola perubahan struktur ekonomi dan penyerapan tenaga kerja tidak mengikuti pola normal. Terdapat beberapa wilayah dimana perubahan strukturnya ekonominya dari sektor primer langsung ke sektor tersier.

\section{METODE PENELITIAN}

Penelitian dilaksanakan selama satu bulan yaitu pada Bulan Februari 2020, dilaksanakan di Kota Kendari Provinsi Sulawesi Tenggara. Karena menggunakan data sekunder maka data penelitian cukup dikumpulkan di BPS baik versi cetak maupun on line. Seluruhan data dalam penelitian ini adalah data sekunder, data tersebut berupa PDB Harga Konstan seri 2010 Tahun 2010-1999 dan data pekerja atar sektor dalam perekonomian nasional Tahun 2010-1999. Data tersebut bersumber dari Badan Pusat Statistik baik versi cetak maupun on line.

Berdasarkan tujuan yang ingin dicapai maka penelitian ini menggunakan metode deskriptif yaitu analisis yang menilai karakteristik dari sebuah data. Analisis tersebut adalah: mean (rata-rata), growth (pertumbuhan) dan proportion (proporsi). Formula yan digunakan adalah:

1. Mean (rata-rata)

$\bar{X}=$ Rata-rata hitung

$$
\bar{X}=\frac{X 1+X 2+X 3+\cdots X n}{N}
$$

$X=$ Nilai pengamatan

$\mathrm{N}$ = Jumlah pengamatan populasi

2. Growth (perumbuhan)

$$
R=\frac{P D R B r t-P D R B r t-1}{P D R B r t-1} \times 100 \%
$$

$\mathrm{R}=$ Laju pertumbuhan ekonomi dalam satuan persen

PDRB rt = Produk Domestik Bruto pada tahun tertentu (rt)

PDRB rt-1 = Produk Domestik Bruto pada tahun sebelumnya (rt-1) 
Jurnal Progres Ekonomi Pembangunan (JPEP)

Volume 5, Nomor 1, Tahun 2020

Page: 83-94

http://ojs.uho.ac.id/index.php/JPEP

3. Proportion (proporsi)

$$
\begin{aligned}
& \qquad \pi=\frac{X}{N} \times 100 \\
& \Pi=\text { Proporsi populasi }(\%) \\
& \mathrm{X}=\text { Jumlah pengamatan } \\
& \mathrm{N}=\text { Jumlah populasi }
\end{aligned}
$$

Untuk memudahkan dalam pemaparan hasil penelitian maka digunakan bantuan matriks dan grafik.

\section{HASIL DAN PEMBAHASAN Hasil Penelitian}

\section{Transformasi Struktur Ekonomi Indonesia}

Tranformasi Struktur Ekonomi adalah pergeseran peranan sektor yaitu dari sektor yang dominan kontrubusinya dalam pembentukan PDB ke sektor yang sebelumnya sebagai sektor yang kontribusinya tidak dominan dalam pembentukan PDB Ada dua indikator yang lazim digunakan dalam melihat transformasi struktur ekonomi yaitu output (PDB) dan penyerapan tenaga kerja. Oleh karena itu membahas transformasi struktur ekonomi senantiasa diawali dengan deskripsi perkembangan PDB selama beberapa tahun.

Secara absolut PDB Indonesia dalam kurung waktu 10 tahun terakhir mengalami pertumbuha rata-rata 5,15 persen per tahun di bawah laju pertumbuhan ekonomi Vietnam $(6,71 \%)$, Laos $(6,50 \%)$ dan Philipina (5,50\%). Pada Tahun 2010 PDB Indonesia tercatat sebesar 6,6 juta milar rupiah bertambah menjadi 10,4 juta miliar pada akhir Tahun 2019. Perkembangan PDB Indonesia selama 10 tahun terakhir disajikan dalam Tabel 1

\section{Tabel 1}

Perkembangan PDB Indonesia ADHK (seri 2010) Tahun 2010-2019 (Miliar Rupiah)

\begin{tabular}{ccc}
\hline Tahun & PDB & $\begin{array}{c}\text { Pertumbuhan } \\
(\boldsymbol{\%})\end{array}$ \\
\hline 2010 & $6.683 .679,80$ & - \\
2011 & $7.142 .634,20$ & 6,87 \\
2012 & $7.560 .262,80$ & 5,85 \\
2013 & $7.953 .312,30$ & 5,20 \\
2014 & $8.351 .368,70$ & 5,00 \\
2015 & $8.699 .535,30$ & 4,17 \\
2016 & $9.097 .697,90$ & 4,58 \\
2017 & $9.531 .259,10$ & 4,77 \\
2018 & $10.003 .188,40$ & 4,95 \\
2019 & $10.499 .611,60$ & 4,96 \\
\hline
\end{tabular}

Sumber: Badan Pusat Statistik (versi Online, 2020)

Jika PDB dilihat berdasarkan sektor utama maka distribusi PDB Indonesia Tahun 2011-2019 didominasi oleh sektor tersier kemudian sektor sekunder dan paling kecil adalah sektor primer. Perkembangan PDB Indonesai berdasarkan sektor utama ditampilkan dalam Tabel 2. 
Jurnal Progres Ekonomi Pembangunan (JPEP)

Volume 5, Nomor 1, Tahun 2020

Page: 83-94

http://ojs.uho.ac.id/index.php/JPEP

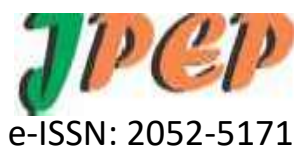

Tabel 2

Perkembangan PDB Indonesia ADHK (seri 2010) Berdasarkan Lapangan Uadaha Tahun 2010-2019 (Miliar Rupiah)

\begin{tabular}{lccccc}
\hline Sektor Utama & $\mathbf{2 0 1 1}$ & $\mathbf{2 0 1 3}$ & $\mathbf{2 0 1 5}$ & $\mathbf{2 0 1 7}$ & $\mathbf{2 0 1 9}$ \\
\hline Primer & 1.742 .814 & 1.874 .196 & 1.938 .773 & 2.038 .054 & 2.161 .164 \\
Sekunder & 1.690 .255 & 1.867 .307 & 2.036 .797 & 2.213 .003 & 2.397 .125 \\
Tersier & 3.709 .565 & 4.211 .809 & 4.723 .965 & 5.280 .202 & 5.941 .323 \\
\hline PDB & $\mathbf{7 . 1 4 2 . 6 3 4}$ & $\mathbf{7 . 9 5 3 . 3 1 2}$ & $\mathbf{8 . 6 9 9 . 5 3 5}$ & $\mathbf{9 . 5 3 1 . 2 5 9}$ & $\mathbf{1 0 . 4 9 9 . 6 1 2}$ \\
\hline
\end{tabular}

Sumber: Badan Pusat Statistik (versi Online; diolah, 2020)

Dominasi sektor tersier tidak hanya tampak pada PDB absolutnya namun tampak pula pada pertumbuhannya tiap tahun serta rata-rata selama 10 tahun terakhir. Pertumbuhan PDB sektor utama ditampilkan dalam Gambar 1.

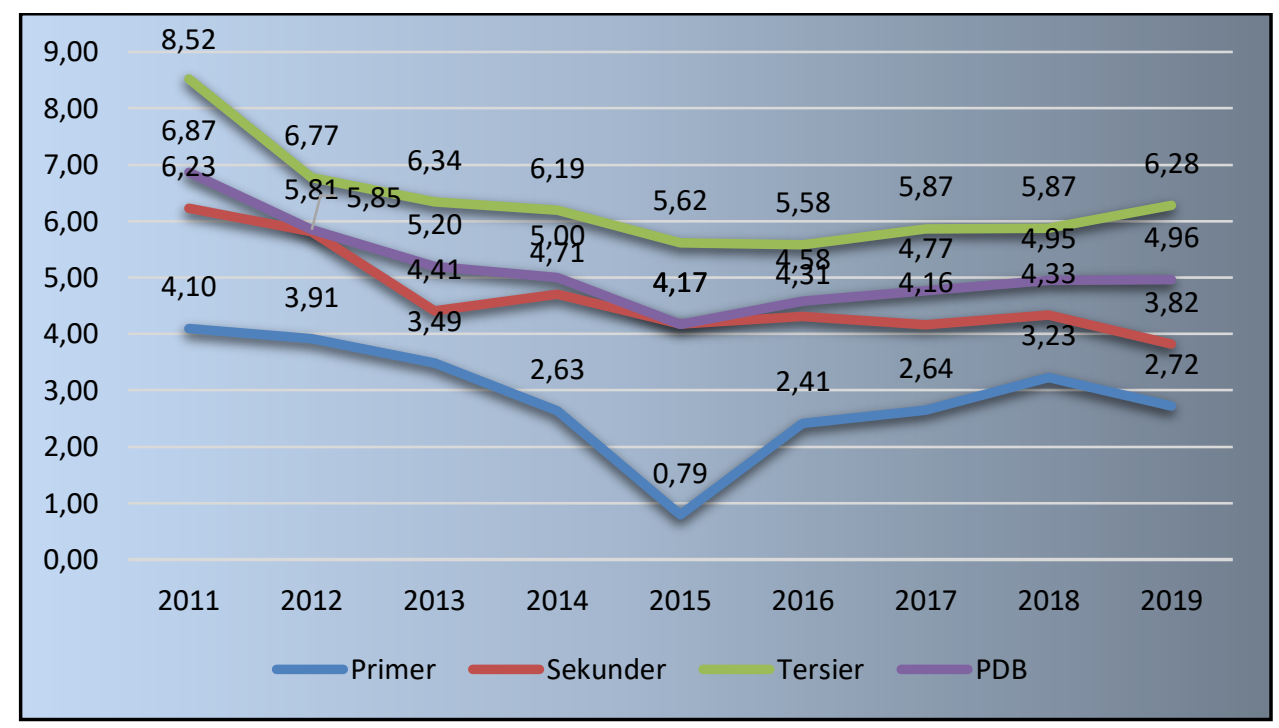

Gambar 1

Pertumbuhan PDB Berdasarkan Sektor Utama Tahun 2011-2019

Sepanjang Tahun 2011-2019 pertumbuhan sektor tersier berada di atas pertumbuhan sektor primer dan sekunder bahkan berada di atas pertumbuhan PDB Indonesia. Pada Tahun 2011 pertumbuhan sektor tersier sebesar 8,52 persen sedangkan PDB hanya tumbuh sebesar 6,87 persen bahkan sektor primer hanya tumbuh sebesar 4,10 persen. Dalam perjalanannya PDB Indonesia mengalami fluktuasi yaitu menurun higga tahun 2015 lalu kemudian mengalami peningkatan pada hingga tahun 2019. Jika dilihat secara sektoral tampak bahwa sektor tersier sejak Tahun 2015 konsisten meningkat namu sektor primer dan sekunder kembali mengalami penurunan.

Tingginya pertumbuhan sektor terseir berdampak pula pada dominasinya terhadap pembentukan PDB. Distribusi peranan sektor perekonomian sepanjang Tahun 2010-2019 tampak pada Gambar 2 di bawah ini. 
Jurnal Progres Ekonomi Pembangunan (JPEP)

Volume 5, Nomor 1, Tahun 2020

Page: 83-94

http://ojs.uho.ac.id/index.php/JPEP

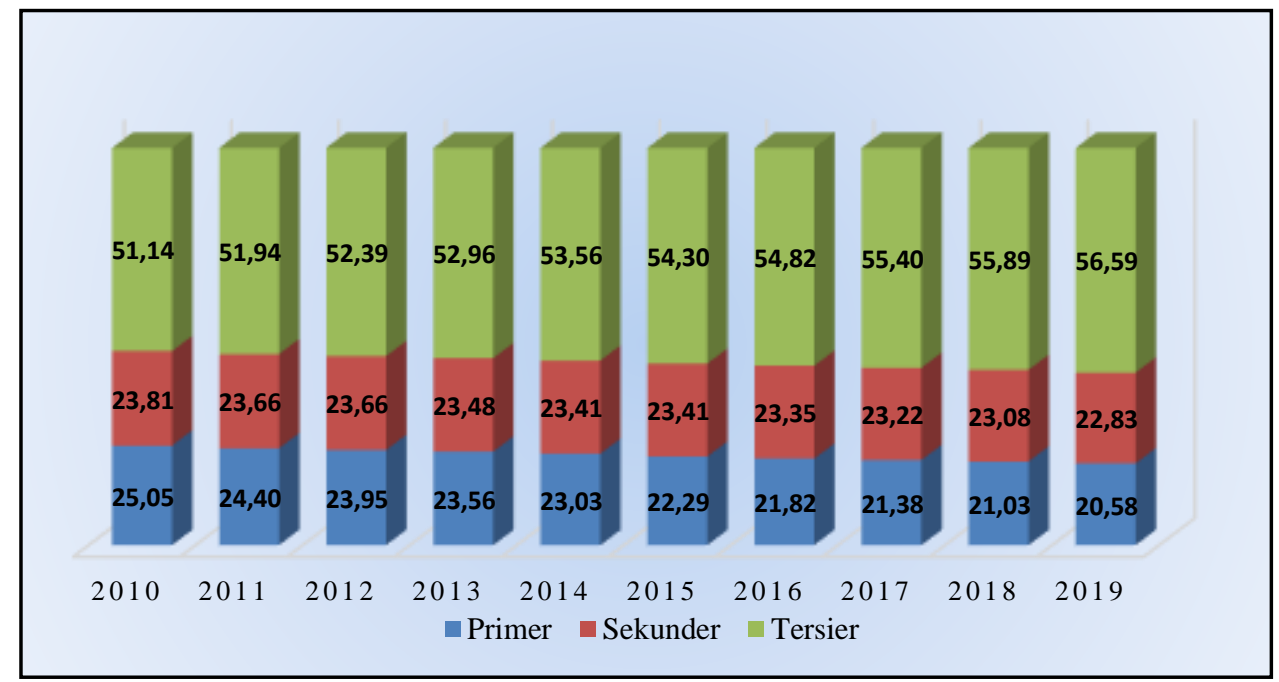

Gambar 2

Distribusi PDB Berdasarkan Sektor Utama Tahun 2010-2019

Peranan sektor tersier dalam pembentukan PDB dalam 10 terakhir sangat dominan dengan trend yang semakin meningkat sedangkan sektor sekunder mengalami perlambatan bahkan sedikit menurun sebaliknya sektor primer memberikan kontribusi yang paling kecil bahkan dengan trend yang semakin menurun. Kontribusi sektor perekonomian dalam pembentukan PDB ditampilkan dalam Gambar 3.

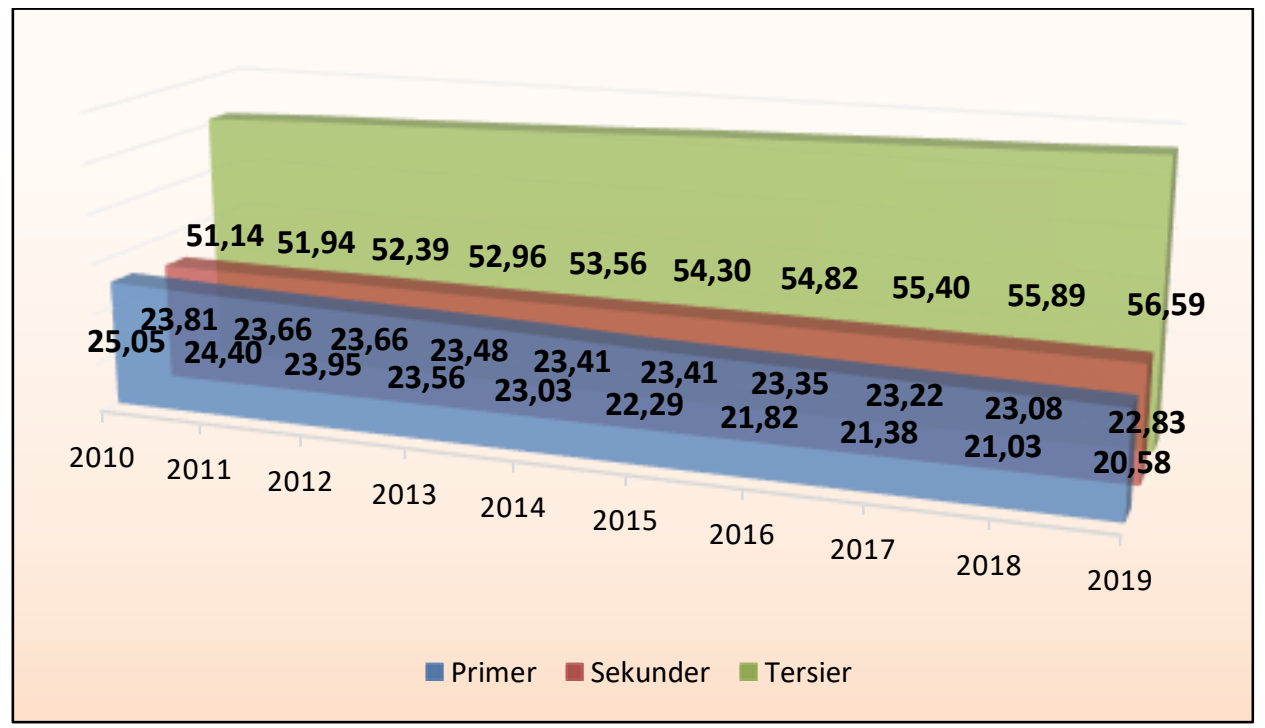

Gambar 3

Kontribusi Sektor Utama Terhadap Pembentukan PDB Tahun 2010-2019

Gambar 3 di atas menunjukkan bahwa peranan sektor primer yang tadinya sebagai sektor utama dalam pembentukan PDB Indonesia yang menyebabkan Indonesia terkenal sebagai negara agraris telah bergeser ke sektor tersier, oleh karena itu berdasarkan output di Indonesia telah terjadi transformasi ekonomi. Transformasi struktur ekonomi tidak saja dilihat berdasarkan output (PDB) namun dapat juga dilihat dari aspek kesempatan kerja apakah perubahan output pada sektor primer juga dikuti oleh pergerakan tenaga kerja. 
Jurnal Progres Ekonomi Pembangunan (JPEP)

Volume 5, Nomor 1, Tahun 2020

Page: 83-94

http://ojs.uho.ac.id/index.php/JPEP

\section{Mobilitas Pekerja Antar Sektor}

Bagian ini dimaksudkan untuk menjelaskan dampak transformasi struktur pada sektor primer terhadap mobilitas pekerja antara sektor, apakah dengan menurunnya persentase output sektor primer menyebabkan berkurangnya daya tampung tenaga kerja pada sektor tersebut dan kalau terjadi mobilitas tenaga kerja ke sektor mana pekerja itu berpindah. Jumlah pekerja pada berbagai sektor perekonomian ditampilkan dalam Tabel 3.

Tabel 3

Penyerapan Tenaga Kerja Antar Sektor di Indonesia Tahun 2010-2019 (Juta orang)

\begin{tabular}{lrrrrrrrrrr}
\hline Sektor & $\mathbf{2 0 1 0}$ & $\mathbf{2 0 1 1}$ & $\mathbf{2 0 1 2}$ & $\mathbf{2 0 1 3}$ & $\mathbf{2 0 1 4}$ & $\mathbf{2 0 1 5}$ & $\mathbf{2 0 1 6}$ & $\mathbf{2 0 1 7}$ & $\mathbf{2 0 1 8}$ & $\mathbf{2 0 1 9}$ \\
\hline Primer & 42,75 & 40,52 & 41,19 & 40,64 & 40,41 & 39,07 & 39,24 & 37,31 & 37,16 & 39,48 \\
Sekunder & 14,13 & 15,18 & 16,50 & 15,93 & 16,05 & 16,01 & 16,38 & 18,28 & 19,06 & 18,96 \\
Tersier & 51,32 & 51,71 & 54,81 & 56,19 & 58,17 & 59,75 & 62,79 & 65,44 & 67,79 & 70,93 \\
\hline Jumlah & $\mathbf{1 0 8 , 2 1}$ & $\mathbf{1 0 7 , 4 2}$ & $\mathbf{1 1 2 , 5 0}$ & $\mathbf{1 1 2 , 7 6}$ & $\mathbf{1 1 4 , 6 3}$ & $\mathbf{1 1 4 , 8 2}$ & $\mathbf{1 1 8 , 4 1}$ & $\mathbf{1 2 1 , 0 2}$ & $\mathbf{1 2 4 , 0 0}$ & $\mathbf{1 2 9 , 3 7}$ \\
\hline
\end{tabular}

Sumber: BPS (versi On line, 2020)

Jumlah penduduk yang bekerja pada sektor tersier cukup besar bahkan meningkat dari tahun ke tahun sedangkan di sektor primer jumlahnya juga masih cukup namun mengalami trend yang menurun. Sebaliknya sektor sekunder adalah sektor yang paling sedikit menyerap tenaga kerja.

Tabel 4

Persentase Pekerja Antar Sektor di Indonesia Tahun 2010-2019

\begin{tabular}{lrrrrrrrrrr}
\hline Sektor & $\mathbf{2 0 1 0}$ & $\mathbf{2 0 1 1}$ & $\mathbf{2 0 1 2}$ & $\mathbf{2 0 1 3}$ & $\mathbf{2 0 1 4}$ & $\mathbf{2 0 1 5}$ & $\mathbf{2 0 1 6}$ & $\mathbf{2 0 1 7}$ & $\mathbf{2 0 1 8}$ & $\mathbf{2 0 1 9}$ \\
\hline Primer & 39,51 & 37,73 & 36,61 & 36,04 & 35,25 & 34,03 & 33,14 & 30,83 & 29,96 & 30,52 \\
Sekunder & 13,06 & 14,13 & 14,67 & 14,12 & 14,00 & 13,94 & 13,83 & 15,10 & 15,37 & 14,65 \\
Tersier & 47,43 & 48,14 & 48,72 & 49,83 & 50,75 & 52,03 & 53,03 & 54,07 & 54,66 & 54,83 \\
\hline Jumlah & $\mathbf{1 0 0 , 0 0}$ & $\mathbf{1 0 0 , 0 0}$ & $\mathbf{1 0 0 , 0 0}$ & $\mathbf{1 0 0 , 0 0}$ & $\mathbf{1 0 0 , 0 0}$ & $\mathbf{1 0 0 , 0 0}$ & $\mathbf{1 0 0 , 0 0}$ & $\mathbf{1 0 0 , 0 0}$ & $\mathbf{1 0 0 , 0 0}$ & $\mathbf{1 0 0 , 0 0}$ \\
\hline
\end{tabular}

Sumber: BPS (versi On line, 2020, diolah)

Pada Tahun 2010 sebanyak 47,43 persen berkerja pada sektor tersier; 39,51 persen di sektor priemer dan hanya 13,06 persen di sektor sekunder. Secara konsisten dari tahun-tahun hingga Tahun 2019 pekerja di sektor tersier terus mengalami peningkatan sebaliknya pada sektor primer mengalami penurunan sedangkan di sektor sekunder disamping jumlahnya kecil juga perkembangannya tidak stabil. Hal ini menunjukkan bahwa transformasi struktur perekonomian dari sektor primer ke sektor tersier diikuti oleh mobilitas pekerja dengan arah yang sama. Perkembangan jumlah pekerja antar sektor ditampilkan dalam Gambar 4.

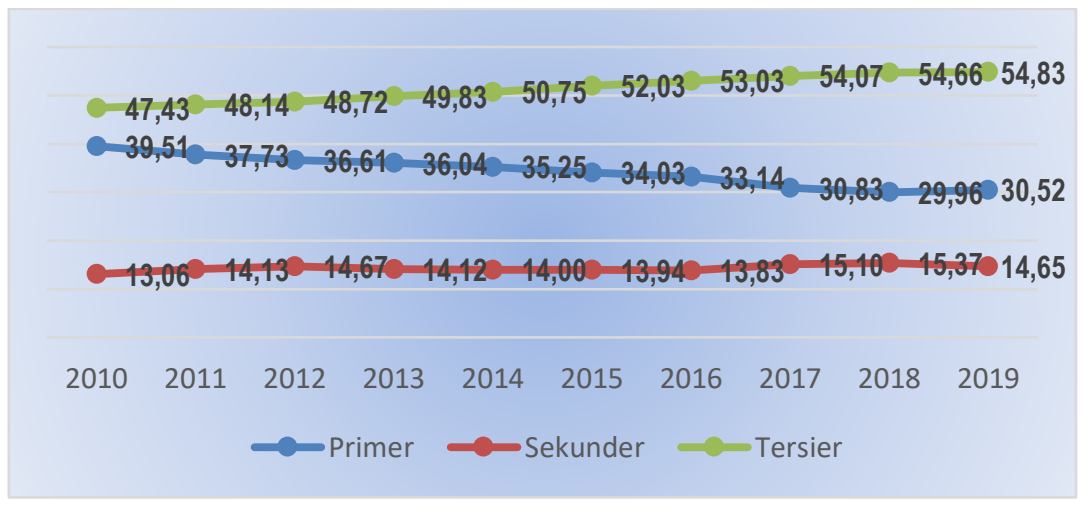

Gambar 4

Perkembangan Jumlah Pekerja Antara Sektor Perekonomian di Indonesia Tahun 2010-2019 (\%) 
Jurnal Progres Ekonomi Pembangunan (JPEP)

Volume 5, Nomor 1, Tahun 2020

Page: 83-94

http://ojs.uho.ac.id/index.php/JPEP

Pembahasan

Terjadi transformasi struktur perekonomian dari sektor primer ke sektor tersier (Tabel 1, Gambar 1, 2, dan 3) hal ini sejalan dengan hasil penelitian Sudarmono (2006) Rumbia (2016), Tajuddin (2017) yang menyimpulkan bahwa terjadi transformasi struktur ekonomi dari sektor primer-teriser-sekunder (Pola P-T-S) yang mereka anggap sebagai pola tidak normal. Hal ini berbeda dengan pola transformasi struktur ekonomi oleh Yingmeri WU (2006), Lewis, Hidayat dan Nazara S (2005), Malunda (2012) dan Margaret MC Milan (2011) serta Chenery dalam teori Pattern of Development yang mengatakan bahwa pembangunan ekonomi berlangsung secara bertahap dari sektor primer ke sektor sekunder kemudian ke sektor tersier.

Terjadinya pola transformasi yang tidak normal di Indonesia dijelaskan oleh Chenery sebagai akibat dari kenaikan income perkapita yang tidak mendorong kenaikan permintaan terhadap barang industri yaitu kondisi yang tidak mendukung perkembangan sektor sekunder. Permintaan barang industri tidak meningkat disebabkan karena kenaikan income perkapita hanya kontribusi dari kenaikan pendapatan kelompok tertentu (konglemerat). Pendapat Chenery diperkuat oleh Tambunan (2009) bahwa wakaupun terjadi tingkat pendapatan rata-rata masyarakat meningkat pesat, tetapi kalau distribusinya pincang makan kenaikan pendapatan tersebut tidak berarti bagi pertumbuhan industri. Sejalan dengan hal tersebut Tajuddin (2017) mengemukakan bahwa pengaruh demonstration effect di Indonesia menyebabkan tingginya permintaan terhadap barang hasil industri besar dari pada permintaan produksi industri kecil dan menengah.

Penurunan peranan sektor pertanian diduga disebebkan oleh adanya berbagai masalah yang dihadapi sektor pertanian (Elieser, 2011) yaitu: (1) rendahnya pengetahuan petani atas akses informasi dan teknologi; (2) kurangnya kepemilikan dan lemahnya akses modal baik modal kerja maupun investasi; (3) semakin terbatasnya lahan yang dapat dipakai untuk bertani.

Perkembangan penduduk yang semakin besar membuat kebutuhan lahan untuk tempat tinggal dan berbagai sarana pendukung lainya juga bertambah. Perkembangan industri juga membuat pertanian beririgasi teknis semakin berkurang (Yingmei WU, et al, 2006).

Tingkat produktivitas pertanian per hektar juga relatif stagnan. Salah satu penyebab dari produktivitas ini adalah karena pasokan air yang mengairi lahan pertanian juga berkurang. Banyak waduk dan bendungan serta saluran irigasi yang ada perlu diperbaiki. Policy (kebijakan) dari pemerintah terlalu ambisius ke sektor manufacturing, bukan ke agroindustri. Pabrik kapal terbang dan manufacturing lainnya memakai investasi yang sangat tinggi, bukan mendorong kemajuan pertanian, bahkan hasil dari pertanianlah dikorbankan. Penurunan kontribusi sektor primer juga disebabkan karena peningkatan pendapatan per kapita penduduk Chenery (1979); Tambunan (2011) dan Sukirno (2007). Peningkatan pendapatan per kapita penduduk mendorong naiknya permintaan barang-barang industri sebaliknya mengurangi permintaan terhadap produk pertanian.

Peningkatan pendapatan per kapita di Indonesia dan negara sedang berkembang lainnya tidak secara proporsional menigkatkan permintaan terhadap barang-barang modal yang akan menjadi dorongan bagi pertumbuhan sektor sekunder namun peningkatan pendapatan lebih berdampak pada meningkatnya konsumsi dan permintaan terhadap jenis barang-barang akhir (final goods) dan lebih mendorong untuk bertambahnya waktu bersantai (laisure) sebagai akibat dari apa yang disebut demonstration effect di negara sedang berkembang.

Transformasi struktur perekonomian dari sektor primer ke sektor tersier diikuti oleh mobilitas pekerja dari sektor primer ke sektor tersier (Tabel 3 dan Gambar 4), kesimpulan ini sejalan dengan teori Lewis tentang migrasi tenaga kerja. Lewis akan terjadi perpindahan tenaga kerja dari sektor tradisional (subsisten) ke sektor moderen. Beberapa faktor yang menyebabkan keunggulan sektor tersier dalam penyerapan tenaga kerja antara lain adalah terbuka luasnya usaha informal dalan sektor jasa. Penurunan kontribusi sektor primer berakibat kurang menariknya bagi pencari kerja baru dan sektor jasa memberikan banyak peluang bagi pencari kerja tersebut. Motif ekonomi menjadi alasan utama permindahan tenaga kerja dari sektor primer ke sektor terseier.

Mantra (1992) menjelaskan bahwa motivasi utama orang melakukan perpindahan dari pedesaan ke perkotaan adalah motif ekonomi. Motif tersebut berkembang karena adanya ketimpangan ekonomi 
Jurnal Progres Ekonomi Pembangunan (JPEP)

Volume 5, Nomor 1, Tahun 2020

Page: 83-94

http://ojs.uho.ac.id/index.php/JPEP

antar daerah. Kondisi yang paling dirasakan menjadi pertimbangan rasional, dimana individu melakukan mobilitas ke kota adalah adanya harapan untuk memperoleh pekerjaan dan memperoleh pendapatan yang lebih tinggi daripada yang diperoleh didesa. Senada dengan hal tersebut, Robert dan Smith (1977) juga memberikan penjelasan seperti dikutip oleh Purnomo (2009) bahwa tidak meratanya pekerjaan dan penghasilan pertanian di pedesaan menjadi motivasi migrasi desa-kota. Motivasi tersebut senada dengan model migrasi Todaro (Todaro, 1992; 1998) yang melandaskan pada asumsi bahwa migrasi dari desa ke kota pada dasarnya merupakan suatu fenomena ekonomi, dimana terdapat perbedaan penghasilan yang diharapkan daripada penghasilan aktual antara desa-kota.

\section{KESIMPULAN DAN SARAN Kesimpulan}

Berdasarkan analisis dan pembahasan disimpulkan bahwa baik berdasarkan ouput (PDB) maupun penyerapan tenaga kerja, di Indonesia telah terjadi transformasi struktur perekonomian dari sektor primer ke sektor tersier. Indonesia tidak layak lagi disebut sebagai negara agraris. Transformasi struktur ekonomi berdasarkan PDB diikuti oleh mobilitas perkerja dari sektor yang sama yaitu dari sektor primer ke sektor tersier.

\section{Saran-Saran}

Mengingat Indonesia memiliki lahan yang luas dan subur serta terdapat banyak kekayaan alam maka kebijakan pemerintah hendaknya berpihak pada upaya pemulihan peran sektor pertanian dengan cara mengembangkan sinergi antara sektor primer dan sektor industri yang didukung oleh sektor tersier. Bagi sektor swasta. Belum diketahui sejak kapan awal terjadinya transformasi atau pengambilalihan peranan sektor primer ke sektor terseir untuk disarankan kepada peneliti selanjutnya untuk menggunakan rentang data (data series) yang lebih panjang.

\section{REFERENSI}

Callaghan, J.R. 1992. Land Use: The Interaction of Economics, Ecology and Hydrology. Chapman \& Hall. London.

Chenery, Hollis B. and Syrquin, Morshe, 1975. Patteren of Development 1950-1970. Washington D.C: The World Bank.

Chenery, Hollis B. and Taylor, 1968. Development Patterens: Among Countries and Overtime. "Review of Economics and Statistics.

Chenery, Hollis B. Robinson, Sherman and Syrquin, Morshe, 1986. Institutional and Growth. New York: Osford University.

Clark, C. 1940. The Condition of Economic Progress. London: Macmillan.

Economic Commission for Africa. 2013, Economic Transformation for Africa's, Development United Nations, Economic Commissin for Afrika.

Elieser Rahman 2011. Sektor Pertanian, http://rahmanelieser. Blogspot.co.id/2011/03/ sektorpertanian.html (diakses pada tanggal 22 Oktober 2016)

Feriyanto Nur, 2015. Structural Transformation Of Economy In Special Region Of Yogyakarta, Jurnal Ekonomi dan Keuangan, Volume 19, Nomor 3,: 360 377

Hill, Hall, 1996. Transformasi Ekonomi Indonesia Sejak 1966: Sebuah Studi Kritis dan Komprehensif. Yogyakarta: PAU (Studi Ekonomi UGM bekerjasama dengan PT. Wacana.

Indrawan Rully. 2014, Pembangunan Inklusif, http://rullyindrawan.files. wordpress.com /2013/05/ diakses pada tanggal 17 April 2014.

Rumbia, Wali Aya, 2015. Analisis Perubahan Struktur Ekonomi dan Struktur Penyerapan Tenaga Kerja Dalam Perekonomian Provinsi Sulawesi Tenggara, Disertasi Pascasarnaja Universitas Halu Oleo Kendari, 2015.

Syrquin, M, 1988. Pattern of Structural Change, Handbook of Development Economics Elsevier Science Publisher. 
Jurnal Progres Ekonomi Pembangunan (JPEP)

Volume 5, Nomor 1, Tahun 2020

Page: 83-94

http://ojs.uho.ac.id/index.php/JPEP

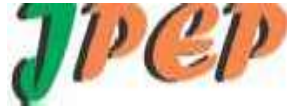

Syrquin, M., 2007. sKuznets and Pasinetti on the Study of Structural Transformation: Never the Twain Shall Meet, Working Paper Series, International Centre for Economic Research.

Tajuddin, 2017. Structure Transformation of Indonesia Economic Year Period 2000-2014. OSR Journal of Business and Management (IOSR-JBM), Vol 19 Issue 5 Ver.V,Mey 2017: 62-69 